\title{
CHOLESTEROL LOWERING EFFECT OF CHITOSAN NANOPARTICLES USING PARIJOTO FRUITS EXTRACT
}

\author{
Fania Putri Luhurningtyas*), Rissa Laila Vifta, Nur Syarohmawati, Mahardika Adhi \\ Candra
}

\author{
Program Studi S1 Farmasi Universitas Ngudi Waluyo, Jl. Diponegoro No. 186, Ungaran Timur, \\ Kabupaten Semarang, Jawa Tengah, 50512, Indonesia
}

Received July 29, 2019; Accepted March 17, 2020

\begin{abstract}
Parijoto (Medinilla speciosa Reinw. ex Blum) fruit is known to have pharmacological activity as cholesterol lowering levels. Its activity needs to be increased with nanoparticle system so that the active substance can bind $100 \%$ to the action target. This study aims to determine the formation of nanoparticles from parijoto fruit (NEBP) and activity test as a decrease in cholesterol levels. The formation of nanoparticles used variations of concentration and volume of chitosan and NaTPP. Anti-cholesterol testing is based on the amount of free cholesterol in the sample that reacted with Lieberman-Burchard into complex green compounds. The best formation of NEBP was $0.2 \%$ chitosan, $0.1 \%$ NaTPP and volume ratio 5:1. The particle size showed an average size of $269.3 \mathrm{~nm}(10-1000 \mathrm{~nm})$. The result of the percent transmittance and polydispersity index were 99,379 (close to 100\%) and 0.378 (PDI <0.5). The functional group-specific of NEBP was $-\mathrm{OH}$, $\mathrm{N}-\mathrm{H}, \mathrm{PO}_{3}$. The morphology was round and non-uniform particles. NEBP can decrease $50 \%$ cholesterol levels with a smaller $\mathrm{EC}_{50}$ value was 89.08 compared to the extract $\left(\mathrm{EC}_{50} 259.98\right.$ ppm). Nanoparticles of parijoto fruit is a potential candidate for anti-cholesterol drug.
\end{abstract}

Keywords: anti-cholesterol; fruit; Medinilla speciosa Reinw. ex Blum; nanoparticles.

\section{INTRODUCTION}

The consumption level of fat intake in Indonesian society is increasing. The increase of the level of fat intake is related to the incidence of cardiovascular disease. In 2030, there will be an estimated 23.6 million people who die of cardiovascular disease (Bastien et al., 2014; Kemenkes RI, 2018). Parijoto fruit is one of the plants preferred by researchers related to its health benefits, especially in degenerative diseases. Parijoto fruit extract is proven to have anti-diabetic, anti-oxidant, anti-bacterial and anti-cholesterol activities (Wachidah, 2013; Sa'adah et al., 2017; Sugiarti et al., 2017; Vifta et al., 2018).

Bioactive compounds contained in parijoto fruit have low weaknesses. That compounds are very sensitive to processing factors, thus increasing the amount of absorbed active substances. The activity of parijoto fruit metabolites needs to be improved by the application of nanotechnology so that the economic value of Parijoto fruit can be increased (Fathinatullabibat et al., 2014; Irawati et al., 2018).

Nanotechnology can be the main solution for active substances with low bioavailability. Nano allocation particles have a very large surface area that makes it easier to use more effectively and easily in passing through the intestinal wall (Elgadir et al., 2015). The nano method that is easy to implement uses polymeric ionic gelation. The basic principle for this method is the presence of electrostatic attraction between oppositely charged molecules. This force can occur between bioactive components and nanocapsule material (Rizvi et al., 2018).

Chitosan or $\alpha$ (1-4) 2-amino 2-deoxy a $\beta$ D-glucane is a form of deacetylation of chitin, 
a biopolymer contained in the exoskeleton of crustaceans and insects. Chitosan has a sensitivity to $\mathrm{pH}$ because it is easily soluble at acidic $\mathrm{pH} \quad(\mathrm{pH}<6.5)$. Chitosan does not dissolve at a higher $\mathrm{pH}$ range. The advantages of chitosan as an encapsulate ingredient that chitosan can prolong the duration of drug activity, improve therapeutic efficiency and reduce side effects (Kleine-brueggeney et al., 2015).

Based on the description above, it is necessary to research the increasing parijoto fruit extract activity through the encapsulation process used chitosan and evaluate its activities as anti-cholesterol. This research is important to provide further results regarding herbal plants in the field of phytopharmaceutical, specifically in herbal plants as anti-cholesterol candidates.

\section{METHODS}

\section{Materials}

Dried parijoto fruit, chemicals used include ethanol 96\%, ethanol pa, glacial acetic acid pa, Liebermann Burchard reagent, concentrated sulfuric acid, anhydrous acetic acid (Merck), chitosan powder (92\% acetylation degree) from Zhejiang GoldenShell Pharmaceuticals, NaTPP (Brataco) powder, distilled and redistilled water (Ikapharmindo Putra Mas), chloroform pa, cholesterol standard (Sigma).

\section{Instrumentations}

Maceration tools, filter paper, laboratory glassware, rotary evaporator (RE 100-Pro), water bath (Memmert), analytic balance (OHAUS), magnetic stirrer (Thermo Scientif Cimarec), a set of centrifugation devices (PLC Series), UV-Vis spectrophotometer (Shimadzu UV Mini 1240), Particle Size Analyzer (Malvern), Fourier Transform Infrared/FTIR spectrophotometer (Perkin Elmer Spectrum 100) and Scanning Electron Microscopy (Phenom Pro-X).

\section{Determination of plants}

Parijoto fruit was obtained from Colo Village, Kudus Regency, Central Java at the beginning of March 2019 with the specification of purplish-pink fruit with a sour taste. The sample was determined at the UPT. Herbal Materia Medica Laboratory, Batu, Malang Health Office to ensure the authenticity of plants used and avoided mistakes in plant selection.

\section{Extraction}

Parijoto was macerated by soaking 200 grams of parijoto dried powder which had been mashed with 2 L ethanol 96\% (1:10). The maceration was carried out for 2 days (48 hours) and followed by re-maceration. Macerate was evaporated by a rotary evaporator at $80^{\circ} \mathrm{C}$ and it was concentrated using water bath at $80^{\circ} \mathrm{C}$. The concentrated extract was calculated as percent yield and percent moisture content.

\section{Nano extract procedure}

NEBP making procedure consists of 2 steps, namely (1) optimization of the concentration of chitosan:NaTPP, and (2) optimization of the volume of chitosan : NaTPP. The extract was weighed $100 \mathrm{mg}$ and dissolved in $100 \mathrm{~mL}$ of ethanol, mixed with 15 $\mathrm{mL}$ of redistilled water. The liquid extract was taken by $10 \mathrm{~mL}$ then $50 \mathrm{~mL}$ of chitosan solution was added with various concentrations $(0.1 \% ; 0.2 \% ; 0.3 \% \mathrm{w} / \mathrm{v})$. In the next step, the solution was stirred at $400 \mathrm{rpm}$ for 20 minutes. Then, gradually added $10 \mathrm{~mL}$ NaTPP with varying concentrations $(0.1 \%$; $0.2 \% \mathrm{w} / \mathrm{v})$. After that, it was homogenized using a magnetic stirrer to form nanoparticles at $400 \mathrm{rpm}$ for 20 minutes and the mixture entered centrifugation process at $3000 \mathrm{rpm}$ for 15 minutes. The obtained supertanant was characterized by particle size, particle distribution (polydispersity index) and transmittance percent.

The best nanoparticle formation result was based on variations in the concentration of chitosan: NaTPP, then it proceeded to search for the formation of the best nanoparticles based on variations in the volume of chitosan: NaTPP. The volume ratio of chitosan: NaTPP used was $2: 1,5: 1,8: 1$, and 10:1. The best formation of nanoparticles was characterized by particle size, percent transmittance, specific functional groups, and shape morphology. 


\section{Test cholesterol reduction activity and data analysis}

The in vitro assay of anti-cholesterol activity was based on research procedures from Anggraini et al. (2018). The nano extract and crude extract $(25,50,75,100,125$ and $150 \mathrm{ppm}$ ) were taken $4 \mathrm{~mL}$, transferred to a test tube with a lid, then added with $1 \mathrm{~mL}$ of $1000 \mathrm{ppm}$ cholesterol stock solution. They were mixed until homogeneous then added 2 $\mathrm{mL}$ of anhydrous acetic acid and $0.1 \mathrm{~mL}$ concentrated $\mathrm{H}_{2} \mathrm{SO}_{4}$. The solution was incubated for 15 minutes in a dark place (the container was covered with aluminum foil) until the color changed to green. The study was replicated 3 times and the color results obtained were read with a UV-Vis spectrophotometer at a maximum wavelength of $623.20 \mathrm{~nm}$. The blank reagent used was 5 $\mathrm{mL}$ chloroform plus $2 \mathrm{ml}$ anhydrous acetic acid and $0.1 \mathrm{ml}$ concentrated $\mathrm{H}_{2} \mathrm{SO}_{4}$. The negative control used was $1 \mathrm{ml}$ of $1000 \mathrm{ppm}$ cholesterol solution in $5 \mathrm{ml}$ of chloroform, plus $2 \mathrm{ml}$ of anhydrous acetic acid and $0.1 \mathrm{ml}$ concentrated $\mathrm{H}_{2} \mathrm{SO}_{4}$.

The parameter for decreasing cholesterol levels is a decrease in color intensity (green). The green color is a reaction between the Liebermann-Burchard reagent and ergocalciferol (cholesterol); a decrease in color intensity is due to the reaction between cholesterol and secondary metabolites (flavonoids) in the parijoto fruit nano-extract. Percent reduction in cholesterol levels used absorbance value data obtained from measurements of NEBP and parijoto fruit extract compared to standard cholesterol solutions.

The percentage formula for decreasing cholesterol levels $=($ Cholesterol Solution Absorbance - Sample Absorbance) / (Cholesterol Solution Absorbance) x 100\%. The statistical test used data of the percentage reduction in cholesterol levels from each concentration treated. The application used SPSS version 24 with the One-Way ANOVA post hoc Tukey HSD to determine the differences in each sample treatment. The $\mathrm{EC}_{50}$ value was obtained based on a linear regression calculation of the reduction in cholesterol levels from each concentration. The $\mathrm{EC}_{50}$ value was the concentration of the sample which can inhibit cholesterol levels by $50 \%$. The purpose of determining the $\mathrm{EC}_{50}$ is to determine the concentration of the dosage which is expected to produce an effect of reducing cholesterol levels by $50 \%$. The result of the equation $y=a+b x$ can be calculated $\mathrm{EC}_{50}$ using the formula:

$\mathrm{Y}=\mathrm{a}+\mathrm{bx}$

$50=\mathrm{a}+\mathrm{bx}$

(x) $\mathrm{EC}_{50}=(50-\mathrm{a}) / \mathrm{b}$

\section{RESULTS AND DISCUSSION \\ Determination}

Plant determination was carried out at the UPT. Materia Medica Batu, Batu City, Malang, East Java. Plant identification key of parijoto is $1 b-2 b-3 b-4 b-12 b-13 a-14 b b-17 b-$ 18b-19b-20b-21b-22b-22b-23b-24b-25b-26b$27 a-28 b-29 b-30 b-31 a-32 b-33 a-34 a-35 a-36 b-$ 1b-4b-6b-9b-10b-14b-15b-16a-17b-18b-20b23b-24b-25b-27b-1b-3a-4a.

Parijoto is a shrub (1-2 meters high) typical of the Muria Mountains, Kudus. The fruit is similar to kersen, purplish red, rounded, and has a distinctive hemispherical section attached to the petals, 5-8 $\mathrm{mm}$ in diameter. The seeds are round, larges, mall, and white (Figure 1).

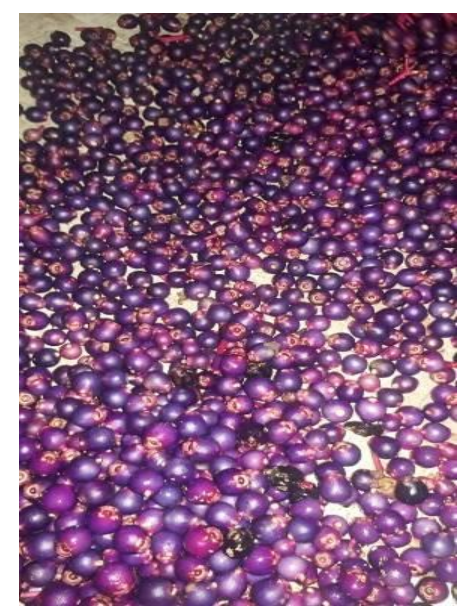

Figure 1. Parijoto fruit 


\section{Characterization of Parijoto Fruit Extract}

The yield of extract was $10.48 \%$ w/v. The percentage of the extract's water content was $4.07 \%$. The identification of moisture content in the extract was supposed to know the minimum limit or range of the amount of water content in the material (extract). The higher the water content is, the easier it is to grow fungi and molds, so that they can reduce the biological activity of extracts in the retention period (Mohammed et al., 2017).

\section{Characterization of nano parijoto fruit extract (NEBP)}

The nanoparticles were made broadly into 2, i.e. top-down and bottom-up. Nano extract in this study used the bottom-up method. It arranges atoms or molecules and combines them through chemical reactions to form nanostructures. Nano parijoto fruit extract (NEBP) is made by the ionic gelation method, which was based on the principle of crosslinking between chitosan cation groups and polyanion in NaTPP.

The NEBP formulation used variations in the concentration of chitosan and NaTPP. The concentration of chitosan used in the formula was obtained by conducting a literature study. The concentration of chitosan was $0.1 \%, 0.2 \%$ and $0.3 \% \mathrm{w} / \mathrm{v}$, the NaTPP concentration was $0.1 \%$ and $0.2 \% \mathrm{w} / \mathrm{v}$ (Sulistyawati et al., 2017). The results of the formation of nanoparticles based on variations in the concentration of chitosan: NaTPP are presented in table 1.

Table 1. The results of NEBP formulation based on concentration variation of

\begin{tabular}{|c|c|c|c|}
\hline \multicolumn{4}{|c|}{ Chitosan:NaTPP } \\
\hline $\begin{array}{c}\text { The } \\
\text { concentration } \\
\text { of Chitosan: } \\
\text { NaTPP }\end{array}$ & $\begin{array}{l}\text { Particle size } \\
\text { (nm) }\end{array}$ & PDI & $\% \mathrm{~T}$ \\
\hline $0,1: 0,1$ & 292,4 & 0,426 & 99,269 \\
\hline $0,2: 0,1$ & 269,3 & 0,372 & 99,379 \\
\hline $0,3: 0,1$ & 1097 & 0,549 & 96,618 \\
\hline $0,1: 0,2$ & 315 & 0,332 & 99,109 \\
\hline $0,2: 0,2$ & 777,9 & 0,513 & 98,274 \\
\hline $0,3: 0,2$ & 1171 & 0,476 & 98,025 \\
\hline$\%$ & $\begin{array}{l}\text { : Polydis } \\
\text { : Percent }\end{array}$ & $\begin{array}{l}\text { rsity it } \\
\text { ansmit }\end{array}$ & \\
\hline
\end{tabular}

The formation of NEBP $0.2 \% \quad \mathrm{w} / \mathrm{v}$ chitosan and $0.1 \% \mathrm{w} / \mathrm{v}$ NaTPP produced the best nanoparticle characteristics. These results follow the study about the synthesis of red mangosteen peel extract which the concentration of $0.2 \%$ chitosan and $0.1 \%$ NaTPP gave the best physical and functional properties with a particle size of $214.4 \mathrm{~nm}$ in Garcinia forbesii extract nanoparticles and $285.2 \mathrm{~nm}$ in Garcinia extract mangosten (Mardliyanti et al., 2012).

Prevention of particle formation at a micro size, chitosan must use concentrations below $0.3 \%$. If the concentration of chitosan used is too small, it will produce small and easily aggregated particle sizes, and it causes a larger particle size. Increasing the concentration of NaTPP with the same concentration of chitosan will also cause a larger particle size. This is because the high concentration of NaTPP results in an increase in the availability of amine groups to combine small particles into larger particles (Ningsih et al., 2017). The small size of nano extract can increase the absorption by the mechanism of diffusion through the intestinal wall and reaches the blood compared to large particles (Shah et al., 2016).

Results of variations in chitosan volume:NaTPP based on particle size, polydispersity index, and transmittance value showed that the best formula obtained was chitosan $0.2 \% \mathrm{w} / \mathrm{v}$ and NaTPP $0.1 \% \mathrm{w} / \mathrm{v}$ with a volume ratio of 5:1 (Table 2). The volume 
ratio greatly influences particle size, polydispersity index, and percent transmittance. Nano parijoto fruit extract made with a volume ratio of $5: 1$ has the smallest particle size and polydispersity index of 269.3 $\mathrm{nm}$ and 0.372 . Increasing the ratio of chitosan and NaTPP will produce nanoparticles with smaller particle size, smaller polydispersity index, and larger percent transmittance.

The polydispersity index value is used to estimate the range of particle size distributions that exist in a sample and finds out whether there is aggregation (Bunglavan et al., 2014). The smaller the polydispersity index value is the more homogeneous the particle size. The polydispersity index value (Table 1 and 2) ranges from 0.3 to 0.7 showed wide particle size distribution. Non-uniform particle size was caused by the tendency of particles to agglomerate to form larger particle aggregates. Factors that can influence particle size and polydispersion index are the concentration of chitosan and crosslinker, the ratio of volume and mass between chitosan solution and crosslinker, stirring speed and stirring time (10). Percent transmittance ( $\% \mathrm{~T})$ is used to measure the clarity of a solution or dispersion system. The percent transmittance value ranges from 98.025-99.379\%. Transmittance values close to $100 \%$ show clear and transparent dispersion.

\section{Characterization of functional groups nano parijoto fruit extract}

The interaction between parijoto fruit extract and chitosan-NaTPP is needed to determine the ability of coating. One method that can be used to determine the presence of extract is Fourier Transform Infra-Red (FTIR). FTIR in this study used 4000-400 $\mathrm{cm}^{-1}$ wavenumbers for extract samples, NaTPP, and chitosan. Parijoto fruit extract used wavenumbers of $4000-600 \mathrm{~cm}^{-1}$. FTIR results can be seen in figure 2 .

Table 2. The results of NEBP formulation based on volume variation of Chitosan: NaTPP

\begin{tabular}{|c|c|c|c|}
\hline $\begin{array}{c}\text { Volume } \\
\text { Chitosan: } \\
\text { NaTPP }\end{array}$ & $\begin{array}{l}\text { Particle size } \\
\quad(n m)\end{array}$ & PDI & $\% \mathrm{~T}$ \\
\hline $2: 1$ & $2.168 \times 10^{4}$ & 0.441 & 98.643 \\
\hline $5: 1$ & 269.3 & 0.372 & 99.379 \\
\hline $8: 1$ & 315.7 & 0.493 & 99.127 \\
\hline $10: 1$ & 346.2 & 0.612 & 98.997 \\
\hline & $\begin{array}{l}\text { : Polydis } \\
\text { : Percent }\end{array}$ & $\begin{array}{l}\text { ty index } \\
\text { smittance }\end{array}$ & \\
\hline
\end{tabular}

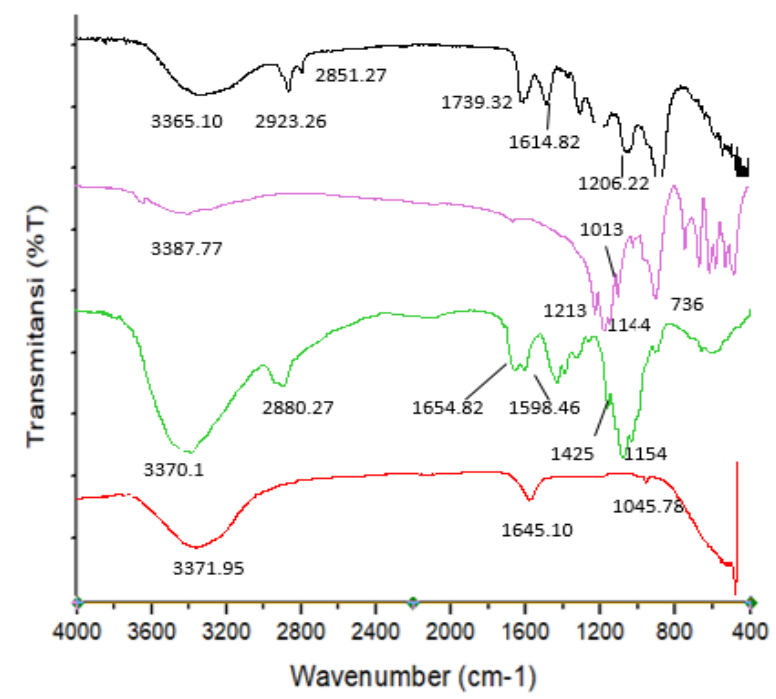

Figure 2. Graph of FTIR results of Ethanol extract of Parijoto fruit (black), NaTPP (purple), Chitosan (green) and Nano Parijoto Fruit Extract (red) 
The transmittance graph of FTIR results on nano parijoto fruit extract (Medinilla speciosa Reinw. Ex Blume) shows that there was an interaction between chitosan, NaTPP, and nano parijoto fruit extract which was indicated by the shift of wavenumber in the group (-OH) from $3370 \mathrm{~cm}^{-1}$ (chitosan), 3387 $\mathrm{cm}^{-1}$ (NaTPP) and $3365 \mathrm{~cm}^{-1}$ (parijoto ethanol extract) to 3371 at nano parijoto fruit extract (Napsah et al., 2014).

At N-H uptake also experienced a shift in wavenumber from twin uptake 1654 and 1598 $\mathrm{cm}^{-1}$ (chitosan) to $1645 \mathrm{~cm}^{-1}$ at nano parijoto fruit extract. This change showed the deformation of the $\mathrm{N}-\mathrm{H}$ group to be one peak because of the cross-linking process (Dewandari et al., 2014). The stretching of the $\mathrm{PO}_{3}$ group at wavenumber of $1045 \mathrm{~cm}^{-1}$ showed the formation of cross bonds between amino groups from chitosan and anionic groups in NaTPP (Lusiana et al., 2018).
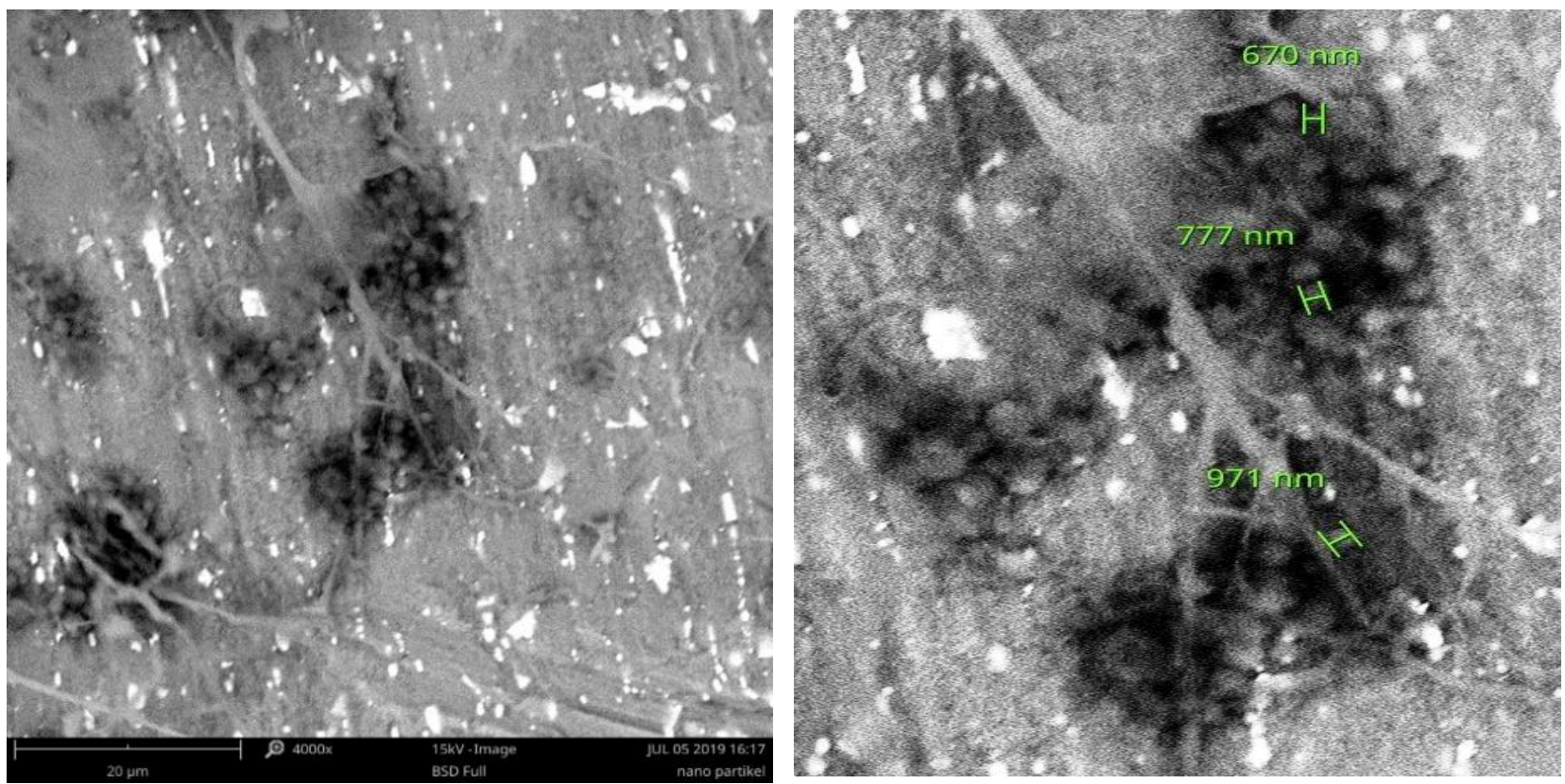

Figure 3. Results of scanning electron microscopy nano Parijoto fruit extract in 4000x zoom 


\section{Determination of maximum waves and operating time}

Determination of maximum wavelength and operating time using the $100 \mathrm{ppm}$ cholesterol which was reacted with anhydrous acetic acid and concentrated $\mathrm{H}_{2} \mathrm{SO}_{4}$ produced the following results: the maximum wavelength of 623.20 and $15^{\text {th }}$-minute operating time. Determination of the value of the operating time is used to determine the timing of the reaction perfectly and stably.

\section{Reduction of the cholesterol level in the Liebermann-Burchard method}

The Lieberman-Burchard method was used to determine the amount of free cholesterol found in samples that reacted to green compounds that could be measured using UV-Vis spectrophotometers. The more concentrated form of green from the solution shows the high free cholesterol contained in the sample solution. The LiebermannBurchard reagent consists of a mixture of anhydrous acetic acid with a small amount of concentrated sulfuric acid. Concentrated sulfuric acid was useful for cutting the hydroxyl group on cholesterol and then oxidized to 3.5 kolekalsiterol (3.5 cholestadienes), resulting in a green color. Anhydrous acetic acid to form acetyl was derived from steroids.

The reaction carried out in this method must be free of water, because the reaction was very sensitive and unstable to water. The presence of water can affect the reaction process and make the compounds formed become unstable. The addition of anhydrous acetic acid is useful for removing water content and ensuring the system to be free of water to form derivative products of acetyl from steroids. The removal of the water content by anhydrous acetic acid is carried out by binding to the $\mathrm{OH}$ and $\mathrm{H}$. Water groups makes the anhydrous acetic acid turn into acetic acid which will not react with concentrated cholesterol and sulfuric acid (Suptijah et al., 2011).

The percentage of cholesterol decrease levels in the concentration of NEBP was greater than the extract (Table 3 ). The result of
$\mathrm{EC}_{50}$ values was inversely proportional to the level of activity of compounds in the sample in reducing cholesterol levels. The smaller the $\mathrm{EC}_{50}$ value is, the stronger the activity of decreasing cholesterol levels.

Table 3. Results of the percentage of inhibition of cholesterol and $\mathrm{EC}_{50}$ value

\begin{tabular}{ccc}
\hline $\begin{array}{c}\text { Concentration } \\
(\mathbf{p p m})\end{array}$ & \multicolumn{2}{c}{$\begin{array}{c}\text { Percentage of Inhibitory } \\
\text { Cholesterol Levels (\%) }\end{array}$} \\
\cline { 2 - 3 } & NEBP & Extract \\
\hline 25 & 14,61 & 6,82 \\
\hline 50 & 25,22 & 14,29 \\
\hline 75 & 41,88 & 20,78 \\
\hline 100 & 62,98 & 24,35 \\
\hline 125 & 71,75 & 27,60 \\
\hline 150 & 78,38 & 28,25 \\
\hline $\mathrm{EC}_{50}$ & 89,08 & 259,98 \\
\hline
\end{tabular}

The ability of NEBP to reduce cholesterol levels by as much as $50 \%$ only requires a small concentration of 89.08 ppm. NEBP can increase the effectiveness of parijoto fruit extract in reducing cholesterol levels which is equal to 3 times greater than the extract. Statistical analysis using Tukey HSD as well as variations in the concentration of nano extract $(150-75 \mathrm{ppm})$ resulted in a reduction in cholesterol levels which differed significantly from the activity of decreasing cholesterol extract ( $\mathrm{p}$-value 0,000). Modification of nanoparticles will help increase the absorption of compounds contained in the extract by increasing the surface area so that the amount of the absorbed substance will increase or, in other words, also increase the effectiveness of the extract (Ferreira et al., 2018). Anti-cholesterol activity in the NEBP concentration of $25 \mathrm{ppm}$ was comparable with the extract concentration of 50 ppm (p-value 1,000). The smallest concentration of nano extract can reduce the dose as much as 2 times compared to the extract, although, based on statistical results, showed no significant difference between the two treatments.

The content of the active ingredient which is considered to have cholesterollowering activity in parijoto fruit is flavonoids. Flavonoids are biologically polar and soluble in water, so they are absorbed poorly due to 
the large particle size. The particle size of these metabolites makes it difficult to absorb through the mechanism of passive diffusion since the lipid solubility is not good so that the ability of compounds to penetrate or penetration to lipid membranes is limited (Anggraini et al., 2017). Nanotechnology is recommended because there are some side effects on the formula that is already available in the market; one of which is influenced by the factor of non-compliant patient because the formulations use large doses and are less effective, there is no clear target specificity.

Nanotechnology can affect the bioavailability and the increase of absorption of active ingredients due to an increase in particle surface area and solubility and has a longer residence time because it is trapped by intestinal mucosa. The increased surface area is due to the smaller particle size, so that the residence time in the intestine will be longer and ensnared by the intestinal mucosa (Napsah et al., 2014). Increasing the effectiveness of parijoto fruit extracts using the ionic gelation nanoparticle technology method can increase effectiveness by using lower doses.

\section{CONCLUSION}

Parijoto fruit extract nanoparticles were successfully synthesized with $0.2 \%$ chitosan and $0.1 \%$ NaTPP. The best volume ratio of chitosan:NaTPP was 5:1. Chitosanencapsulated parijoto fruit extract based on the percentage reduction in levels and $\mathrm{EC}_{50}$ values had a greater cholesterol-lowering activity compared to parijoto fruit extract $(\mathrm{p}<0.05)$. Nano parijoto fruit extract can be used as a potential candidate for anti-cholesterol drugs. It is necessary to find out the optimum dosage of nano extract in vivo test assay.

\section{ACKNOWLEDGEMENT}

Acknowledgments to the Ministry of Research, Technology and Higher Education for funding this research through the Beginner Lecturer Research Program in 2018, colleagues from the research team of nano parijoto fruit extracts, and colleagues from Ngudi Waluyo University, Programme Study of Pharmacy.

\section{REFERENCES}

Anggraini, D.I., Nabillah, L.F. 2018. Activity test of suji leaf extract (dracaena angustifolia roxb.) on in vitro cholesterol lowering. Jurnal Kimia Sains dan Aplikasi, 21(2), 54-58.

Anggraini, D.I., Lily Fathrah N. 2017. Activity test of suji leaf extract (dracaena angustifolia roxb.) on in vitro cholesterol lowering. Journal of Scientific and Applied Chemistry, 21(2), 54-58.

Bastien, M., Poirier, P., Lemieux, I., Després, J.P. 2014. Overview of epidemiology and contribution of obesity to cardiovascular disease. Progress in cardiovascular diseases, 56, (4), 369-381

Bhosale, A.P., Patil, A., Swami, M. 2015. Herbosomes as a novel drug delivery system for absorption enhancement. World Journal of Pharmacy and Pharmaceutical Sciences, 5(1), 345-355.

Bunglavan, S.J., Garg, A.K., Dass, R.S., Shrivastava, S. 2014. Use of nanoparticles as feed additives to improve digestion and absorption in livestock. Livest. Res. Int, 2, 36-47.

Dewandari, K.T., Yuliani, S., Sedamawati, S. 2013. Ekstraksi, karakterisasi nanopartikel ekstrak sirih merah (piper crocatum). Jurnal Pascapanen, 10 (2), 58-65.

Elgadir, M.A., Uddin, M.S., Ferdosh, S., Adam, A., Chowdhury, A.J.K., Sarker, M.Z.I. 2015. Impact of chitosan composites and chitosan nanoparticle composites on various drug delivery systems: A review. Journal of food and drug analysis, 23(4), 619-629.

Fathinatullabibah, F., Khasanah, L.U., Kawiji, K. 2014. Stabilitas antosianin ekstrak daun jati (Tectona grandis) terhadap perlakuan $\mathrm{pH}$, suhu. Jurnal Aplikasi Teknologi Pangan, 3(2), 60-63. 
Ferreira-Tomaz, A., Sobral de Carvalho, S., Barbosa, C.R., L Silva, S., Sabino Gutierrez, M., B de Lima, A., L Fook, M. 2018. Ionically crosslinked chitosan membranes used as drug carriers for cancer therapy applications. Materials. 11(10), 2051.

Irawati, T., Mardiana, Y. 2018. Stabilitas antosianin dari ekstrak buah mangsi (phyllanthus reticulatus poir). Jurnal Ilmiah Hijau Cendekia, 3(2), 26-29.

Kleine-brueggeney, H., Zorzi, G.K., Fecker, T., El Gueddari, N.E., Moerschbacher, B.M., Goycoolea, F.M. 2015. A Rational approach towards the design of chitosanbased nanoparticles obtained by ionotropic gelation. Colloids and Surfaces B: Biointerfaces, 135, 99-108.

Lusiana, R.A., Wahyu P.P. 2018. Membran kitosan termodifikasi tripolifosfatheparin, aplikasinya pada permeasi urea, kreatinin. Analytical and Enviromental Chemistry, 3(1), 11-21.

Mardliyati, E., Muttaqien, S.E., Setyawati, D. R. 2012. Sintesis nanopartikel kitosantrypoly phosphate dengan metode gelasi ionik: pengaruh konsentrasi, rasio volume terhadap karakteristik partikel. Prosiding Pertemuan Ilmiah Ilmu Pengetahuan, Teknologi Bahan.

Mohammed, M., Syeda, J., Wasan, K., Wasan, E. 2017. An overview of chitosan nanoparticles and its application in nonparenteral drug delivery. Pharmaceutics, 9(4), 53.

Najib, A., Malik, A., Ahmad, A.R., Handayani, V., Syarif, R.A., Waris, R. 2017. Standarisasi ekstrak air daun jati belanda, teh hijau. Jurnal Fitofarmaka Indonesia, 4(2), 241-245.

Napsah, R., Wahyuningsih, I. 2014. Preparasi nanopartikel kitosan-tpp/ekstrak etanol daging buah mahkota dewa (phaleriamacrocarpa (scheff) boerl) dengan metode gelasi ionik. Jurnal Farmasi Sains dan Komunitas, 11(1), 712.

Ningsih, N., Sedarnawati Y., Sri Y. 2017. Sintesis nanopartikel ekstrak kulit manggis merah, kajian sifat fungsional produk enkapsulasinya. Jurnal Teknologi, Industri Pangan, 28(1), 27-35.

Republik Indonesia, Kementerian Kesehatan. 2018. Hasil utama riskesdas 2018. Jakarta: Badan Penelitian, Pengembangan Kesehatan.

Rizvi, S.A., Saleh, A.M. 2018. Applications of nanoparticle systems in drug delivery technology. Saudi Pharmaceutical Journal, 26(1), 64-70.

Sa'adah, N.N., Purwani, K.I., Nurhayati, A. P.D., Ashuri, N.M. 2017. Analysis of lipid profile and atherogenic index in hyperlipidemic rat (rattus norvegicus berkenhout, 1769) that given the methanolic extract of parijoto (medinilla speciosa). AIP Conference Proceedings, 1854(1), AIP Publishing.

Shah, B.R., Li, Y., Jin, W., An, Y., He, L., Li, Z., Li, B. 2016. Preparation and optimization of Pickering emulsion stabilized by chitosan-tripolyphosphate nanoparticles for curcumin encapsulation. Food Hydrocolloids, 52, 369-377.

Sugiarti, L., Pujiastuti, E. 2017. Uji aktivitas antibakteri ektrak etanol buah parijoto (medinilla speciosa blume) terhadap bakteri staphylococcus aureus, echerichia coli. Cendekia Journal of Pharmacy, $1(1), 25-33$.

Sulistyawati, R., Nurani, L.H., Hidayati, S., Mursyidi, A., Mustofa, M. Standarisasi kualitas fraksi etil asetat daun kelor (moringa oleifera lamk.). URECOL. 6772.

Suptijah, P., Jacoeb, A.M., Rachmania, D. 2011. Karakterisasi nano kitosan cangkang udang vannamei (litopenaeus vannamei) dengan metode gelasi ionik. Jurnal Pengolahan Hasil Perikanan Indonesia, 14(2), 78-84.

Vifta, R., Advistasari, Y.D. 2018. Analisis penurunan kadar glukosa fraksi n-heksan buah parijoto (medinilla speciosa b) secara in vitro dengan metode spektrofotometri uv-vis. Indonesian Journal of Chemical Science, 7(3), 249253.

Wachidah, L.N. 2013. Uji aktivitas antioksidan, serta penentuan kandungan 
fenolat, flavonoid total dari buah parijoto

(medinilla speciosa blume). Fakultas

Kedokteran, Ilmu Kesehatan UIN Syarif

Hidayatullah, Jakarta. 